\title{
HUBUNGAN KEMAMPUAN MANAJERIAL, MOTIVASI KERJA, DAN PERSEPSI PENGELOLA TERHADAP PROGRAM PEMBERDAYAAN DENGAN MUTU PELAYANAN PKBM DI KABUPATEN GARUT
}

\author{
Uum Suminar
}

\begin{abstract}
The growth of Society Learning Activities Centre (PKBM) in quantity/amount, has not been balanced againts the quality improvement, especially in its services. One of factors influencing the quality of $P K B M$ sevices is organizer resource factor. The target of this research is to lay open how far the relation of managerial ability, work motivation, and organizer perception to empowerment program with the quality of PKBM services.

This research uses the quantitative approach. Problem focus analysis is conducted with the correlation descriptive analysis method, because this research is to lay open the relation of researched variables. Research population is 93 organizers of PKBM in Garut. Sampling technique used is simple random by proportional to 54 organizer people from 11 PKBM. Questionaire is used to collect the data. The conclusion of this research is there are significant relations between organizer managerial ability with the service quality, there are significant relations between motivation of work with the service quality, there are significant relations between organizer perception to empowerment program with the service quality, and there are significant relations between merger variables together with the service quality of PKBM.
\end{abstract}

Keywords: managerial ability, work motivation, perception to empowerment program, quality service.

\section{PENDAHULUAN}

\section{Latar Belakang Masalah}

Perkembangan PKBM sejak diluncurkan pada tahun 1998 menunjukkan pertumbuhan yang cukup pesat, teridentifikasi sampai saat ini sebanyak 1.500 unit lebih yang tersebar di seluruh Indonesia. Kemajuan yang pesat ini menimbulkan kegairahan dan kegembiraan yang tak terkira bagi insan akademisi maupun praktisi PLS. Namun seiring dengan itu banyak pula menuai kritik yang tidak pernah sepi baik dari masyarakat maupun pemerhati pendidikan. Mengapa tidak? Karena harapannya, semakin banyak lembaga PKBM ini terbentuk akan semakin banyak pula masyarakat yang terlayani, setidaknya dapat dijadikan sebagai alat pengentas kemiskinan. Namun kenyataannya, banyaknya PKBM yang muncul tidak diikuti dengan meningkatnya jumlah masyarakat yang terlayani. Menurut Zainudin Arif (2001) terdapat perbedaan antara harapan dengan kenyataan tersebut dapat dipahami karena dalam pengelolaannya Pusat Kegiatan Belajar Masyarakat mempunyai beberapa perbedaan dalam komponennya. Komponen pertama adalah pengelola bentuknya sangat beragam ada yang berbentuk yayasan, perorangan, organisasi masyarakat atau keagamaan, pondok pesantren, lembaga swadaya

\footnotetext{
* Mantan Kepala UPTD SKB Garut
}

masyarakat, dan lain-lain. Komponen kedua, mutu sumber daya manusia yang mengelola PKBM. Komponen ketiga, kemampuan dana masing-masing pengelola. Komponen keempat pengadaan sarana dan prasarana. Adanya perbedaan yang mendasar dari masing-masing komponen tersebut menyebabkan adanya perbedaan mutu pengelolaan PKBM. Secara umum rendahnya mutu pengelolaan PKBM diakibatkan oleh sedikitnya mencakup tiga hal yaitu mutu input, mutu proses dan mutu output. Mutu input berkaitan dengan ketersediaan dan kesiapan. Mutu proses berkaitan dengan keharmonisan dan sinergi semua input sehingga mampu menciptakan situasi belajar yang menyenangkan, memotivasi warga belajar, warga belajar tidak hanya sekedar tahu dan terampil, tetapi mampu menerapkan pengetahuan dan keterampilannya dalam kehidupan sehari-hari. Mutu output berkaitan dengan hasil belajar akademik yang tinggi dan hasil belajar nonakademik seperti kejujuran, disiplin, ketekunan, mandiri, peningkatan pendapatan, kesehatan, dan lain-lain.

PKBM pada hakekatnya dibentuk dengan tujuan untuk memperluas kesempatan bagi warga masyarakat khususnya yang tidak mampu meningkatkan pengetahuan, keterampilan dan sikap mental yang 
diperlukan untuk mengembangkan diri dan bekerja mencari nafkah. Upaya untuk meningkatkan mutu pengelolaan dan pengembangan Pusat Kegiatan Belajar Masyarakat menurut Djudju Sudjana (2003:1), diperlukan:

Strategi pengelolaan PKBM yang sesuai dengan pengelolaan program pendidikan luar sekolah, mencakup fungsi-fungsi perencanaan, pengorganisasian, penggerakan, pembinaan (pengawasan, supervisi, monitoring), dan penilaian. Dan strategi pengembangan merupakan upaya memantapkan, memperluas, dan meningkatkan kualitas pengelolaan dan program-program Pusat kegiatan Belajar Masyarakat. Pengelolaan PKBM dilakukan dengan menggunakan pendekatan kemanusiaan, kolaboratif, partisipatif, berkelanjutan, dan budaya. Pendekatan kemanusiaan (humanistic approach) memberikan arti bahwa dalam pengelolaan PKBM maka masyarakat, warga belajar, dan sumber daya manusia lainnya dipandang sebagai subjek, bukan objek. Pendekatan partisipatif (participatory approach) mengandung arti bahwa penyelenggara, pengelola dan pendamping PKBM berupaya seoptimal mungkin melibatkan warga masyarakat dan lembaga terkait dalam melaksanakan fungsi-fungsi pengelolaan. Pendekatan berkelanjutan (continuation approach) mengandung makna bahwa kegiatan PKBM dan pelaksanaan fungsi-fungsi pengelolaannya dilakukan secara terus menerus. Pendekatan budaya (cultural approach) memberikan arah kepada penyelenggara, pengelola dan pendamping PKBM untuk dapat menghargai budaya termasuk tradisi dan adat istiadat yang berkembang di masyarakat.

Pengelola merupakan salah satu bagian dari komponen instrumental input dalam manajemen PKBM dituntut memiliki kemampuan manajerial yang dapat berkontribusi pada berkualitas tidaknya suatu pelayanan. Oleh karena itu tidak berlebihan jika pandangan-pandangan para ahli manajemen seperti John P. Kotter, Edwin A. Locke, maupun, Kouzes dan Posner memberikan tanggapan yang cukup menentukan tentang peranan pemimpin atau penglola dan kepemimpinannya. Menurut Jhon P. Kotter "kepemimpinan adalah kemampuan menetapkan suatu arah yang dapat dirasakan, membuat orang-orang menyelaraskan diri ke arah itu, dan memberi mereka kekuatan untuk mencapainya dengan cara apapun. Jadi di sini seorang pemimpin ataupun pengelola adalah kumpulan (agregasi) kualitas-kualitas intelektual, pengertian tentang ekologi kemanusiaan serta ciri-ciri moral yang memungkinkan seseorang untuk membangkitkan motivasi lain guna melaksanakan tugas yang ditetapkan. Pendapat tersebut sesuai dengan pandangan Edwin A. Locke, yang mengemukakan bahwa kepemimpinan merupakan proses membujuk (inducing) orang-orang lain untuk mengambil langkah menuju suatu sasaran bersama. Selain itu juga, kepemimpinan adalah suatu hubungan timbal balik antara mereka yang memilih untuk memimpin dan mereka yang memutuskan untuk mengikuti.

Pengelola PKBM termasuk jenis tenaga kependidikan PNF. Dengan demikian pengelola PKBM dituntut untuk memiliki pandangan stratejik yang jauh ke depan dan kekuatan tekad yang besar, sekaligus ia dapat menerjemahkan visinya sehingga di mengerti oleh peserta belajarnya. Visi saja tidak cukup, ia dituntut untuk memiliki task commitment yang kuat, memiliki motivasi kerja yang kokoh dalam mewujudkan prestasi yang diharapkan. Dalam aspek motivasi ini, David McClelland menyebutnya sebagai the need for achievement yang dikenal dengan N'ach. Need for achievement tersebut merupakan nafsu untuk bekerja keras, belajar lebih cepat, ulet, dan disiplin. Namun juga tidak semata-mata untuk kepuasan ekonomi, melainkan juga untuk memuaskan secara sosial dan batin dari dalam. Oleh karena itu pula dikembangkan need for power (N'power) dan need for affiliation (N'affiliation).

Aspek lain yang tidak kalah pentingnya dalam upaya meningkatkan mutu pelayanan PKBM, adalah persepsi pengelola terhadap program pemberdayaan. Pemberdayaan pengelola PKBM secara sederhana mencakup pengembangan konsep-konsep "mandiri", "partisipasi", "jaringan kerja", dan "keadilan" dalam pembangunan masyarakat (Craig \& Mayo, 1995). Namun dalam prakteknya upaya untuk meningkatkan mutu pelayanan PKBM itu tidaklah mudah karena permasalahan krusial itu sering muncul karena "tiadanya respon berantai untuk perbaikan kualitas". Untuk itulah peneliti ingin lebih jauh meneliti tentang "Hubungan Kemampuan Manajerial, Motivasi Kerja, dan Persepsi Pengelola Terhadap Program Pemberdayaan dengan Mutu Pelayanan PKBM di Kabupaten Garut".

\section{Identifikasi Masalah}

Pengelolaan PKBM sebagai suatu proses kegiatan yang dimulai dari perencanaan, pelaksanaan dan diakhiri dengan penilaian. Mutu pengelolaan PKBM sangat dipengaruhi oleh mutu komponen-komponen sebagai berikut.

1. Masukan lingkungan (environmental input), yang terdiri dari lingkungan alam, lingkungan sosial, dan kelembagaan.

2. Masukan sarana (instrumental input) seperti: tenaga kependidikan (penyelenggara/ pengelola), tenaga pendidik (tutor, pamong belajar, pelatih, nara Jurnal IImiah VISI PTK-PNF - Vol. 2, No.1 - $2007 \quad 83$ 
sumber). Fasilitas dan perlengkapan (panti belajar, alat dan bahan), dan biaya.

3. Masukan lain (other input) seperti pendidikan, organisasi, dan kelembagaan.

Pengelola PKBM merupakan salah satu unsur dalam komponen instrumental input yang berperan sebagai perencana, pelaksana, penggerak, pembina, penilai dan pengembang kegiatan setiap program (layanan pendidikan, layanan informasi, kemitraan, dan pengendalian). Untuk tercapainya tujuan organisasi tersebut dibutuhkan pengelola yang memiliki performance yang berkualitas. Sedikitnya ada dua hal yang mempengaruhi performance seorang pengelola tersebut yaitu faktor internal dan faktor eksternal. Faktor internal seperti kreativitas, kemampuan, motivasi, sikap, minat, kepribadian, dan lain-lain. Sedangkan faktor eksternal meliputi; pendidikan, pengalaman, pelatihan, fasilitasi/pemberdayaan, dan sebagainya.

Faktor internal yang mempengaruhi performance pengelola dalam tulisan ini dibatasi kepada kemampuan manajerial dan motivasi kerja. Sedangkan faktor eksternalnya adalah persepsi pengelola terhadap program pemberdayaan.

\section{Perumusan Masalah}

Fokus permasalahan penelitian adalah "Bagaimanakah hubungan antara kemampuan manajerial, motivasi kerja, dan persepsi pengelola terhadap program pemberdayaan dengan mutu pelayanan PKBM di Kabupaten Garut"?

Rumusan masalahnya dirinci dalam empat pertanyaan penelitian, yakni sebagai berikut.

1. Bagaimanakah hubungan antara kemampuan manajerial dengan mutu pelayanan PKBM?

2. Bagaimanakah hubungan antara motivasi kerja dengan mutu pelayanan PKBM?

3. Bagaimanakah hubungan antara persepsi pengelola terhadap program pemberdayaan dengan mutu pelayanan PKBM?

4. Bagaimanakah hubungan antara kemampuan manajerial, motivasi kerja dan persepsi pengelola terhadap program pemberdayaan dengan mutu pelayanan program PKBM?

\section{Kerangka Pemikiran}

Kerangka berfikir yang digunakan penelitian ini sebagai berikut.

Pertama, kemampuan manajerial sebagai variabel bebas kesatu ditandai dengan (X1) merupakan faktor internal yang dapat mempengaruhi terhadap variabel terikat. Aspek-aspeknya adalah sebagai berikut. a. Kemampuan berpikir: kelancaran (fluency), fleksibelitas (flexibility), orisinalitas (originality), dan elaborasi (elaboration).

b. Kemampuan bersikap: rasa ingin tahu (curiosity), keberanian mengambil resiko (risk taking), tertantang oleh kemajemukan (tolerance for ambiguity), percaya diri (self confidence).

c. Kemampuan skill: keterampilan menjalankan tugas (task commitment skill), keterampilan memberikan penguatan (reinforcement skill), keterampilan mengadakan variasi (variation skill)

Kedua, motivasi kerja merupakan variabel bebas kedua ditandai dengan (X2). Motivasi kerja ini merupakan faktor internal yang dapat mempengaruhi berhasil tidaknya variabel terikat (Y). Aspek-aspeknya adalah sebagai berikut.

a. Motif: merupakan dorongan maupun kebutuhan untuk berprestasi (need for achievement), kebutuhan akan afiliasi (need affiliation), dan kebutuhan akan kekuatan (need for power)

b. Harapan: kadar keyakinan (instrumentalitas), kekuatan untuk mencapai hasil (valensi), keyakinan akan hasil tertentu (expectancy).

c. Imbalan merupakan penguatan/hadiah dari diri sendiri (intrinsik) maupun imbalan dari luar (ekstrinsik).

Ketiga, program pemberdayaan sebagai variabel bebas ketiga yang ditandai dengan (X3) merupakan faktor eksternal yang dapat mempengaruhi terhadap variabel terikat. Aspek-aspeknya meliputi:

a. perencanaan meliputi: identifikasi masalah, penawaran program, perumusan program, perencanaan tindakan;

b. pelaksanaan merupakan pengembangan dalam: pendekatan, strategi, metode / strategi pemecahan masalah; dan

c. evaluasi merupakan penilaian yang meliputi: penilaian proses dan hasil.

Keempat, mutu Pelayanan PKBM sebagai variabel terikat yang ditandai dengan (Y). Variabel ini merupakan hasil dari kinerja atau performance pengelola dalam pelayanan pendidikan, pelayanan informasi, jalinan kemitraan, dan pengendalian program PKBM. Mutu pelayanan tersebut meliputi: konsistensi dan ketepatan (reliability), tanggap dan cepat (responsivness), kepastian/jaminan (assurance), mengenal/merasakan jiwa orang lain (empathy), dan keterukuran (tangibles). Aspek-aspek yang terkandung dalam variabel ini meliputi kriteria standar pelayanan minimal manajemen PKBM yang terdiri atas:

a. program layanan pendidikan: ditinjau dari sepuluh patokan dikmas (warga belajar, sumber belajar, 
pengelola, sarana belajar, panti belajar, program belajar, dana belajar, ragi belajar, evaluasi belajar, dan hasil belajar) setiap program;

b. program layanan informasi: layanan tehadap warga belajar, kelompok, dan masyarakat; c. program jalinan kemitraan: kerjasama, bantuan, dan hibah; dan

d. program pengendalian: supervisi, pengawasan, evaluasi, monitoring.

\section{KAJIAN PUSTAKA}

\section{Pusat Kegiatan Belajar Masyarakat}

Terminologi "Pusat Kegiatan Belajar Masyarakat" yang disingkat PKBM, memiliki makna yang beragam tergantung dari sisi mana kita memandang. Lembaga PBB-UNESCO (1993) yang membawahi bidang-bidang pendidikan, sosial, dan kebudayaan, merumuskan bahwa Pusat Kegiatan Belajar Masyarakat merupakan wadah atau tempat di mana orang-orang dapat mengikuti program kegiatan belajar. Badan Penelitian dan Pengembangan Departemen Pendidikan Nasional memberi pengertian lain tentang PKBM sebagai tempat kegiatan pembelajaran masyarakat yang diarahkan pada pemberdayaan potensi desa untuk menggerakan pembangunan di bidang sosial, ekonomi, dan budaya. Selanjutnya dalam Undang-Undang No. 20 Tahun 2003 tentang Sistem Pendidikan Nasional, Bagian Kelima: Pendidikan Nonformal Pasal 26 ayat 4: PKBM adalah sebagai satuan pendidikan nonformal. UNESCO (2003:1) mendefinisikan Community Learning Center (CLC) adalah pusat pertukaran informasi dan kegiatan belajar sepanjang hayat bagi masyarakat agar memiliki daya. Secara filosofis makna PKBM sebagai:

Pusat, bermakna pemusatan manajemen, bukan dalam pengertian pemusatan berbagai program layanan PKBM pada satu tempat. Pemusatan manajemen penyelenggaraan PKBM, terutama dalam hal pemecahan masalah. Kegiatan belajar, setiap program atau kegiatan layanan PKBM diselenggarakan dalam setting pembelajaran sehingga proses dan hasil program dan kegiatan layanan diikuti dan diperoleh warga sasaran program harus berdampak kepada perubahan pengetahuan, sikap dan keterampilan. Masyarakat, merupakan sasaran utama dan sasaran akhir dari setiap program/kegiatan layanan yang dirancang oleh PKBM. (BPKB Jayagiri, 2003)

PKBM dipandang sebagai suatu pendekatan pembelajaran memiliki azas dan fungsi yang bermuara pada kemanfaatan bagi masyarakat dalam perspektif yang lebih luas. Tujuh azas yang melandasi PKBM sebagai suatu pendekatan yaitu azas kemanfaatan, kebermaknaan, kebersamaan, kemandirian, keselarasan, kebutuhan, dan tolong menolong. Tujuh azas tersebut mempunyai arti sebagai berikut: Kesatu; azas kemanfaatan yaitu setiap kehadiran PKBM harus memberikan manfaat bagi masyarakat sekitar dalam upaya memperbaiki kesejahteraannya. Kedua, azas kebermaknaan, yaitu PKBM dengan segala potensinya harus mampu memberikan dan menciptakan program yang bermakna dan dapat meningkatkan kualitas kehidupan masyarakat sekitar. Ketiga, azas kebersamaan, yaitu PKBM merupakan lembaga yang dikelola secara bersama-sama, bukan milik perorangan, kelompok atau golongan tertentu serta bukan milik pemerintah. Oleh karena PKBM milik bersama, digunakan bersama serta untuk kepentingan bersama. Keempat, azas kemandirian, yaitu PKBM dalam pelaksanaan dan pengembangan kegiatan harus mengutamakan kekuatan dan potensi yang dimiliki sendiri, yang kalaupun ada bantuan dari pihak lain hanya berupa stimulan untuk membangkitkan kemampuan yang lebih besar dimiliki sendiri; Kelima, azas keselarasan, yaitu setiap kegiatan yang dilaksanakan harus sesuai dan selaras dengan situasi dan kondisi masyarakat sekitar. Keenam, azas kebutuhan, artinya setiap kegiatan yang dilaksanakan merupakan kegiatan pembelajaran yang benar-benar mendesak dan dibutuhkan masyarakat. Ke tujuh, azas tolong menolong artinya PKBM merupakan arena atau ajang pembelajaran masyarakat yang didasarkan rasa saling asah asih, dan asuh diantara sesama warga masyarakat itu sendiri dalam kerangka saling membelajarkan.

Sebagai lembaga yang dibentuk dari, oleh, dan untuk masyarakat, PKBM memiliki fungsi sebagaii wadah pembelajaran, tempat pusaran semua potensi masyarakat, pusat dan sumber informasi, ajang tukar menukar keterampilan dan pengalaman, sentra pertemuan antara pengelola dan sumber belajar, sebagai lokasi belajar yang tidak pernah sepi pembelajaran

Bentuk penyelenggaraan PKBM memiliki jenis yang berbeda seperti yang dikemukaan UNESCO (1993) sebagai berikut.

PKBM yang berbasis masyarakat, yaitu suatu PKBM yang diorganisir masyarakat dan semua sarana serta prasarana, sumber daya manusia, dana dan program pendidikan berasal dan ditentukan oleh 
masyarakat. PKBM berbasis kelembagaan, yaitu suatu PKBM yang diorganisir oleh pemerintah, dan semua sarana/prasarana, sumber daya manusia, dana, organisasi dan programnya berasal dari pemerintah. PKBM yang berbasis komprehensif, yaitu PKBM yang merupakan kombinasi antara PKBM yang berbasis kelembagaan dan PKBM yang berbasis masyarakat. (Zainudin Arif, 2001)

Jenis PKBM berbasis masyarakat lebih banyak dikembangkan dengan harapan dapat menumbuhkan prakarsa masyarakat lebih luas untuk menjadi subjek dan objek belajar. PKBM inipun diharapkan mampu memberikan kontribusi besar terhadap peningkatan kualitas sumber daya manusia dengan memberdayakan potensi lingkungan masyarakatnya. Program-program yang dikembangkan di PKBM meliputi programprogram yang dapat ditinjau berdasarkan ruang lingkup, satuan pendidikan, dan jenis pendidikan.

\section{Mutu Pelayanan}

Istilah "mutu" atau "kualitas", dalam Kamus Besar Bahasa Indonesia, menunjuk kepada suatu ukuran baik buruk suatu benda; kadar; taraf atau derajat (kepandaian, kecerdasan, dan sebagainya) (Depdikbud, 1991: 677). Dengan demikian konsep "mutu” atau "kualitas" pada hakikatnya berkaitan dengan standar sesuatu benda, jasa, hasil usaha lainnya dalam membandingkan dengan yang lain.

Zainudin Arif (2001) mengemukakan konsep mutu tidak hanya dilihat dari sudut keluaran (output) program pendidikan, tetapi konsep mutu juga dilihat dari segi proses, masukan (input) serta konteks. Lebih lanjut beliau menyatakan bahwa pengukuran terhadap mutu program misalnya mutu pendidikan luar sekolah mempunyai perspektif yang berbeda untuk setiap program. Program yang disusun untuk tujuan penguasaan terhadap suatu keterampilan untuk peningkatan pendapatan akan berbeda dengan program pendidikan luar sekolah yang dirancang untuk tujuan peningkatan dan pengembangan diri bagi warga belajar. Oleh karena itu tujuan dan variasi input setiap program pendidikan luar sekolah berbeda, maka ukuran mutu suatu program pendidikan luar sekolah juga akan berbeda untuk setiap program pendidikan luar sekolah.

Pelayanan diartikan oleh Thoha (1993: 39) sebagai suatu usaha yang dilakukan oleh seseorang atau kelompok orang atau instansi tertentu untuk memberikan bantuan dan kemudahan kepada masyarakat dalam rangka mencapai suatu tujuan tertentu. Mutu pelayanan, merupakan bagian integral yang tidak bisa dipisahkan dalam manajemen pendidikan. Salah satu upaya ternama dalam mengembangkan manajemen kualitas adalah apa yang dinamakan "Reaksi Berantai Perbaikan Kualitas" atau yang dikenal dengan "Program Deming" (diambil dari nama perintis TQM atau Total Management Quality yang dilakukan Dr. Edwards Deming dalam me-recovery perekonomian Jepang Pasca Perang Dunia II). Premis tersebut menyatakan: "Apabila kualitas diperbaiki, biaya akan turun dan produktivitas naik" (Hardjosoedarmo, 1999: 186). Model untuk menggambarkan peningkatan mutu pelayanan suatu organisasi yang dapat divisualisasikan dalam gambar 2 berikut.

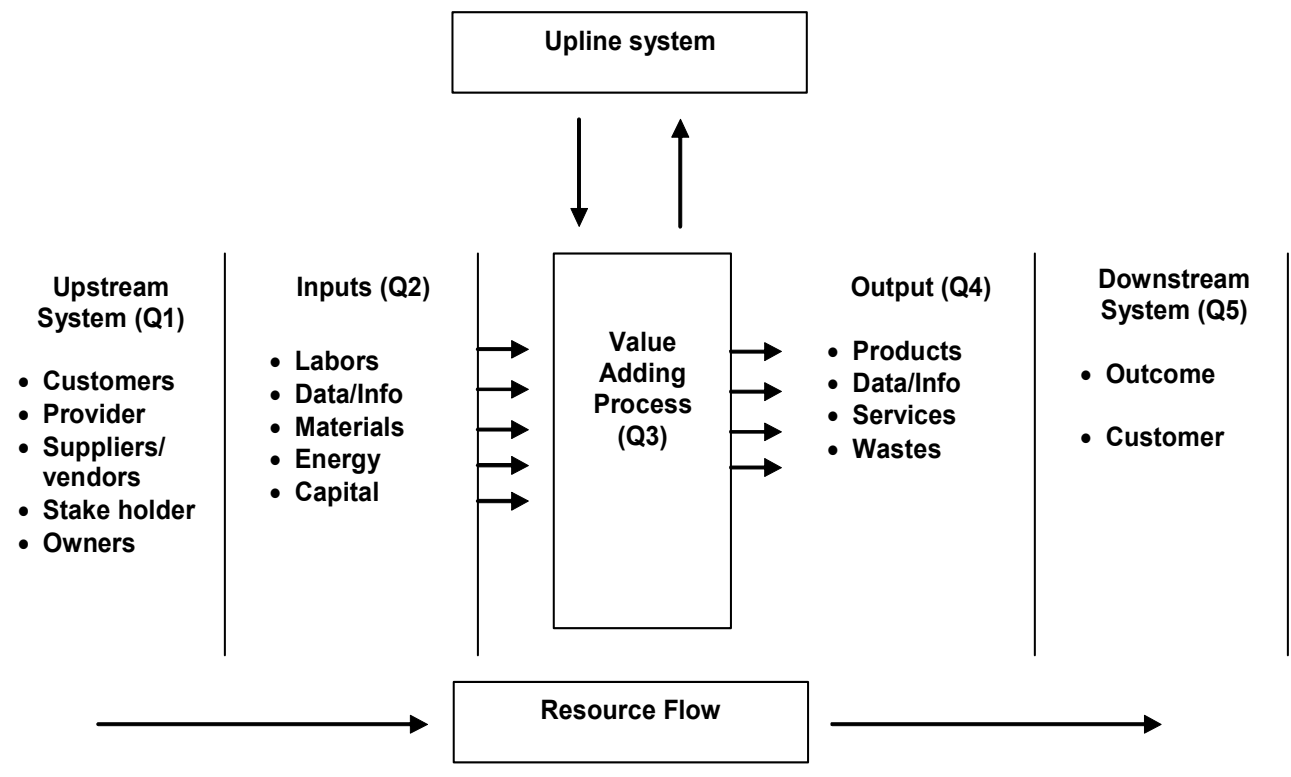

Gambar 1. Input-Output Analisis Sistem Organisasi

(Diadaptasi dari Scott D. Sink dan Tutle C. Thomas Planing and Measurenment in Your Organization of the Future Industrial Engineering and Management Press, NorCorm, Georgia, 1989.) 
Karakteristik mutu pelayanan program PKBM yang dapat ditunjukkan oleh pengelola seperti berikut.

a. Reliability: kemauan untuk memberikan layanan yang tepat kepada warga belajar.

b. Tangibles: fasilitas fisik, peralatan, personil dan komunikasi.

c. Responsiveness, kemauan untuk membantu warga belajar.

d. Competence: pengetahuan dan keterampilan yang dimiliki.

e. Courtesy: sikap atau perilaku ramah bersahabat, tanggap terhadap keinginan warga belajar.

f. Credibility: sikap jujur dalam setiap upaya untuk menarik kepercayaan masyarakat.

g. Security: pelayanan yang diberikan dijamin bebas dari berbagai bahaya dan resiko.

h. Access: terdapat kemudahan untuk mengadakan kontak dan pendekatan.

i. Communications: kemauan untuk memberikan layanan yang aspiratif, sekaligus kesediaan untuk menyampaikan informasi baru kepada masyarakat.

\section{Kemampuan Manajerial}

Pengertian kemampun identik dengan pengertian kreativitas, seperti yang dikemukakan Supriadi (1994:16) bahwa "setiap orang memiliki kemampuan kreatif dengan tingkat yang berbeda-beda". Tidak ada orang yang sama sekali tidak memiliki kemampuan atau kreativitas, dan yang diperlukan adalah bagaimanakah mengembangkan kreativitas tersebut. Ada juga pendapat yang mengemukakan bahwa kreativitas merupakan suatu kemampuan yang dimiliki oleh setiap orang,potensi kreatif ini dapat dikembangkan atau dipupuk. Pendapat ini didukung oleh Piers (1976:268) yang mengemukakan bahwa kondisi ini menunjukkan bahwa karya kreatif tidak lahir karena hanya kebetulan, melainkan melalui serangkaian proses kreatif yang menuntut kecakapan, keterampilan, dan motivasi yang kuat. Semiawan (1984:8) mengartikan kreativitas sebagai kemampuan untuk membuat kombinasi-kombinasi barau antar unsure dan atau halhal yang sudah ada

Ciri-ciri pokok seseorang dikatakan kreatif apabila memiliki kemampuan yang bisa dipertanggungjawabkan.Ciri-ciri itu dapat digolongkan sebagai berikut. 1. Kelincahan mental-berfikir dari segala arah. Kelincahan mental adalah kemampuan untuk bermain-main dengan ide-ide atau gagasangagasan, konsep, kata-kata dan sebagainya. Berpikir dari segala arah (convergent thinking) adalah kemampuan untuk melihat masalah atau perkara dari berbagai arah, segi dan mengumpulkan berbagai fakta yang penting dan mengarahkan fakta itu pada masalah atau perkara yang dihadapi.

2. Kelincahan mental-berpikir ke segala arah. Berpikir ke segala arah (divergent thinking) adalah kemampuan untuk berpikir dari ide-ide atau gagasan, menyebar ke segala arah;

3. Fleksibilitas konsep (conceptual flexibility) adalah kemampuan untuk secara spontan mengganti cara memandang, pendekatan, kerja yang tidak jalan.

4. Orisinalitas (originality) adalah kemampuan untuk menelorkan ide, gagasan, pemecahan, cara kerja yang tidak lazim, yang jarang bahkan "mengejutkan".

5. Lebih menyukai kompleksitas dari pada simplisitas. Orang yang kreatif dan mampu itu lebih baik menyukai kerumitan daripada kemudahan, dengan maksud untuk memperkaya dan memperluas cakrawala berpikir.

6. Latar belakang yang merangsang (simulating backround) adalah lingkungan dan suasana yang mendorong untuk mempelajari.

7. Pengetahuan, melatih kecakapan baru dan untuk memiliki sifat-sifat khas mereka: usaha, tenang dalam kegagalan, tidak putus asa, disiplin, mencaricari terus, berprestasi dan gairah dalam hidup.

8. Kecakapan dalam banyak hal. Pada umumnya orang yang memiliki kemampuan mempunyai banyak minat dan kecakapan dalam berbagai bidang (multiple skills).

Jack Hallorar (Hendrik, 1989: 52) mengemukakan bahwa ciri-ciri orang yang memiliki kemampuan dan kreatif meliputi:

1. orang yang kreatif mengelola ingin tahunya secara baik. Intelektualnya giat bekerja dan dinamis,

2. orang yang berani berpikir dan berprasangka terhadap masalah yang menantangnya,

3. orang yang terbuka dan menerima informasi, misalnya meminta informasi dari rekannya untuk keperluan memcahkan masalah,

4. orang yang matang dan konseptual melalui penelitian dalam mengahadapi masalah, dan

5. orang yang mandiri (independent). la bekerja sendiri tanpa menggantungkan dari pada orang lain.

Kemampuan manajerial seorang pengelola dapat digambarkan sebagai berikut.

1. Keterampilan Menjalankan Tugas.

Kemampuan ini sangat dipengaruhi oleh bekal pengetahuan dan keterampilan yang dimiliki pengelola. Melalui peran seorang pimpinan keterampilan pengelola ini akan berkembang dengan cara: meningkatkan volume pekerjaan, membangkitkan minat, mengembangkan pola

Jurnal IImiah VISI PTK-PNF - Vol. 2, No.1 - 2007 
berpikir yang baik, menuntun proses berpikir, dan memusatkan perhatian terhadap masalah yang ditangani.

2. Keterampilan Memberikan Penguatan (Reinforcement Skill).

Penguatan atau reinforcement adalah segala bentuk respon, apakah bersifar verbal ( bisa diungkapkan atau diutarakan dengan kata-kata langsung sepertrti; baik, sukses, benar dan sebagainya) maupun non verbal (biasanya dilakukan dengan gerak, isyarat, pendekatan dan sebagainya), yang merupakan bagian dari modifikasi tingkah laku atau kebijakan pimpinan terhadap bawahannya atas pekerjaannya sebagai suatu tindakan dorongan atau koreksi.

Reinforcement dapat berarti juga respon terhadap suatu tingkah laku yang dapat meningkatkan kemungkinan berulangnya kembali tingkah laku tersebut. Tujuan penguatan yang diharapkan berpengaruh positif terhadap sikap individu adalah untuk: meningkatkan perhatian, motivasi kerja, dan gairah.

3. Keterampilan Mengadakan Variasi (Variation Skill) Variasi pemberian rangsangan (motif) seseorang adalah suatu kegiatan dalam proses interaksi tugas di lapangan yang ditujukan untuk mengatasi kebosanan dalam situasi bekerja. Manfaat variation skill adalah: meningkatkan perhatian, mengembangkan prakarsa, memupuk perilaku positif.

Kemampuan manajerial Pengelola PKBM dapat ditinjau dari karakteristik kemampuan terhadap standar minimal manajemen pelayanan adalah sebagai berikut.

1. Perencanaan. Melakukan pendataan umum, masalah atau kebutuhan dan sumber daya pendukungnya. Menyusun prioritas kebutuhan program masing-masing bidang, yaitu bidang layanan pendidikan, layanan informasi, kemitraan, dan peningkatan mutu kependidikan.

2. Pengorganisasian. Menyiapkan dan menggerakan sumber daya yang teridentifikasi. Mengkaji dan menata sumber daya yang akan dimanfaatkan sesuai dengan kebutuhan atau tuntutan program kegiatan. Menata pelaksana-an program kegiatan. Menata tenaga kependidikan.

3. Pelaksanaan dan Pengendalian. Di bidang pendidikan: (1) memotivasi warga belajar, (2) mengadakan atau mengembangkan bahan belajar pokok bagi warga belajar dan bahan pengajaran pokok bagi tutor dan nara sumber, (3) melaksanakan proses belajar pembelajaran, (4) menilai proses dan hasil kegiatan belajar mengajar secara berkala. $\mathrm{Di}$ bidang pelayanan informasi: menyusun dan atau menggandakan bahan belajar, memberikan layanan informasi. Di bidang kemitraan atau kerjasama, melaksanakan dan mengembangkan jaringan kemitraan atau kerjasama fungsional. Di bidang pembinaan teknis tenaga kependidikan, melaksanakan atau menyelenggarakan pembinaan teknis kependidikan baik secara mandiri maupun atas fasilitasi pembina teknis. Di bidang pemantauan dan pengendalian, melaksanakan pemantauan dan pengendalian pelaksanaan program kegiatan.

4. Penilaian. Mengukur tingkat pencapaian tujuan penyusunan. Menyusun rekomendasi hasil pengukuran dan bahan masukan rencana kerja tahunan. Menyusun laporan tahunan tentang penyelenggraraan PKBM.

\section{Motivasi Kerja}

"Motivasi" berasal dari kata "motif" yang artinya daya atau tenaga pendorong (drives), dalam mencapai kebutuhan (needs) atau untuk mencapai tujuan atau goals (Thoha, 1993: 180). Kemudian, istilah "motivasi" lebih diperjelas lagi sebagi suatu daya dorong, penimbul hasrat dan upaya dalam memenuhi kebutuhan maupun tujuan yang sifatnya merupakan suatu proses, relatif tetap, dan berkesinambungan. Jika ditinjau dari unsurunsurnya, maka motivasi itu meliputi: dorongan (drive), kebutuhan (needs), dan tujuan (goals). Diantara tiga unsur tersebut sebenarnya saling berinteraksi satu sama lain dan berbaur dalam satu tindakan atau perbuatan manusia yang terintegrasi. Tujuan, adalah sesuatu yang ingin dicapai atau harapan yang berada di luar diri individu. Kebutuhan, adalah dorongan yang membuat seseorang itu berperilaku. Maslow mengemukakan bahwa orang dewasa secara normal memuaskan kira-kira $85 \%$ kebutuhan fisiologis, $70 \%$ kebutuhan rasa aman, 50\% kebutuhan untuk memiliki dan mencintai, $40 \%$ kebutuhan harga diri, dan hanya $10 \%$ dari kebutuhan aktualisasi diri. Dalam studi motivasi lainnya, Mc Clelland (1961) mengemukakan adanya tiga macam kebutuhan yang ingin dipenuhi manusia adalah: kebutuhan untuk berprestasi (Need for Achievement), Kebutuhan untuk berhubungan social (Need for Affiliation), dan kebutuhan untuk kekuasaan (Need for Power).

Motivasi kerja merupakan bentuk perilaku seseorang yang ditentukan oleh faktor keinginannya untuk mencapai kebutuhan dan tujuan. Motivasi kerja yang didorong oleh upaya pemenuhan kebutuhan akan selalu berubah-ubah sesuai dengan kadar yang sudah dipenuhinya. Kebutuhan dapat didefinisikan sebagai suatu kesenjangan antau pertentangan yang dialami antar suatu kenyataan dengan dorongan yang ada 
dalam diri. Apabila kebutuhan terpenuhi maka seseorang akan merasa gembira dan sebaliknya jika kebutuhannya tidak terpenuhi akan kecewa. Alasanalasan yang mendorong manusia untuk melakukan sesuatu karena kebutuhan prestasi, afiliasi, dan kekuasaan. Kekuatan motivasi bagi seseorang itu dapat berubah sewaktu-waktu. Perubahan itu terjadi karena kepuasan kebutuhan yakni seseorang telah mencapai kepuasan atas kebutuhan yang diinginkannya

Motivasi kerja pengelola dasar utamanya adalah pengetahuan dan perhatian terhadap perilaku manusia yang dipimpinnya. Sebagai suatu faktor penentu keberhasilan organisasi, faktor manusia perlu mendapat perhatian serius pada semua permasalahan kebutuhannya. Seorang pemimpin yang berhasil dalam melaksanakan fungsi motivasi adalah pemimpin yang mempunyai kemampuan untuk merealisasikan adanya sinkronisasi antar tujuan pribadi para anggota organisasi dengan tujuan organisasi itu sendiri. Dengan demikian pengelola yang memiliki motivasi kerja merasa penting untuk memberikan bantuan fasilitas kepada organisasi dan individu yang akan mendukung kelancaran pelaksanaan pekerjaan sehingga menciptakan layanan PKBM yang bermutu. Proses memotivasi yang baik memerlukan langkah-langkah sebagai berikut: (1) Memprioritaskan kebutuhan yang tidak dipenuhi, (2) Mencari jalan untuk memenuhi kebutuhan, (3) Perilaku yang berorientasi pada tujuan, (4) Hasil karya , (5) Imbalan atau hukuman.

Pelaksanaan pemotivasian agar efektif memerlukan prinsip-prinsip sebagai berikut, Prinsip Mengikutsertakan Bawahan, Prinsip Komunikasi, Prinsip Pengakuan, Prinsip Wewenang yang Didelegasikan, Prinsip Timbal Balik.

\section{METODOLOGI PENELITIAN}

\section{Pendekatan dan Metode Penelitian}

Penelitian ini menggunakan pendekatan kuantitatif. Analisa terhadap fokus permasalahan dilakukan dengan menggunakan metode analisis deskriptif korelasional. Tujuan penelitian deskriptif adalah untuk membuat deskripsi atau lukisan secara sistematis, faktual dan akurat mengenai fakta-fakta serta hubungan antar fenomena yang diselidiki. Sedangkan penelitian korelasional ialah penelitian yang menggambarkan dan menaksir data yang ada, kemudian dilanjutkan dengan analisis dan interpretasi tentang arti data. Melalui analisis tersebut diharapkan diperoleh jawaban terhadap hipotesis yang diajukan.

\section{Populasi}

PKBM yang terbentuk di Kabupaten Garut seluruhnya berjumlah 44 lembaga, dan pada umumnya PKBM berbasis yayasan dan pesantren. PKBM yang berbasis masyarakat sudah terbentuk sejak tahun 2001 sebanyak 11 lembaga. Jumlah populasi pengelola PKBM kabupaten Garut sebagai berikut.

Tabel 1. Populasi penelitian

\begin{tabular}{|c|l|c|}
\hline No & \multicolumn{1}{|c|}{ PKBM Dikabupaten Garut } & Jumlah \\
\hline 1 & PKBM Lepmi desa Cidadar kecamatan Cisurupan & 8 \\
\hline 2 & PKBM AlKhoir desa Jayawaras kecamatan Tarogong Kidul & 9 \\
\hline 3 & PKBm Tunas Melati desa situsari kecamatan Karangpawitan & 8 \\
\hline 4 & PKBM Al-Hidayah desa Sukasono kecamatan Sukawening & 9 \\
\hline 5 & PKBM Nurul Hikmah desa Wanaraja kecamatan Wanaraja & 9 \\
\hline 6 & PKBM Jati Asri desa Jati kecamatan Tarogong Kaler & 9 \\
\hline 7 & PKBM Attamimi desa Sukasenang kecamatan Sukaresmi & 7 \\
\hline 8 & PKBM Al-Falah desa Sukajadi kecamatan Bayongbong & 9 \\
\hline 9 & PKBM Fisabililah desa Samarang kecamatan Samarang & 9 \\
\hline 10 & PKBM Sawargi desa Sawargi kecamatan Singajaya & 8 \\
\hline 11 & PKBM Al-Khoeriyah desa Limbangan Kecamatan Limbangan & 93 \\
\hline & & Jumlah \\
\hline
\end{tabular}

\section{Sampel}

Sampel merupakan sebagian atau wakil populasi yang diteliti menyangkut karakteristik dan jumlahnya. Teknik sampling yang digunakan adalah sampling acak sederhana. Dalam penelitian ini jumlah populasi sebanyak 93 orang dari 11 PKBM, banyaknya sampel yang diperoleh adalah 48 orang dengan menggunakan rumus sebagai berikut . 
Hubungan Kemampuan Manajerial, Motivasi ...

$$
n=\frac{n_{0}}{1+\frac{\left(n_{0}-1\right)}{N}} \text { dengan } n_{0}=\frac{1}{4}\left(\frac{Z_{(1-\alpha / 2)}}{d}\right)^{2}
$$

(Harun Al Rasyid 1994 : 44)

\section{Teknik dan Alat Pengumpul Data}

Data-data yang diperlukan, sesuai dengan fokus permasalahan penelitian, dikumpulkan melalui wawancara, observasi dan menggunakan kuisioner serta dokumentasi. Kuisioner digunakan untuk mengumpulkan data yang berhubungan dengan variabel-variabel seperti variabel bebas $(X)$ yakni kemampuan manajerial (X1), motivasi kerja (X2), persepsi pengelola terhadap program pemberdayaan (X3) . Sedangkan untuk variabel terikat yakni mutu pelayanan program PKBM $(\mathrm{Y})$, selain menggunakan kuisioner juga menggunakan observasi dan catatancatatan atau dokumentasi tentang prestasi kerja pengelola yang menjadi responden dalam penelitian ini.

\section{Langkah-langkah Pengumpulan Data}

Penyusunan Kuesioner digunakan untuk mengumpulkan data yang berhubungan dengan variabel-variabel: (X1) sebanyak 30 item, (X2) sebanyak 27 item, $(X 3)$ sebanyak 23 item. Dan $(Y)$ sebanyak 20 item. Uji validitas instrumen dengan menggunakan rumus korelasi product moment $r$ dari Pearson dengan taraf signifikansi $5 \%$. Uji reliabilitas instrumen menggunakan koefisien reliabilitas Alpha Cronbach.

\section{Teknik Pengolahan Data dan analisis Data}

Perhitungan kecenderungan umum responden, menstransformasi data melalui MSI (Metode Successive Interval), pemeriksaan distribusi data, uji hipotesis dengan analisis regresi dan analisis korelasi

\section{Hipotesis}

1. Terdapat hubungan yang signifikan antara kemampuan manajerial dengan mutu pelayanan PKBM

2. Terdapat hubungan yang signifikan antara motivasi kerja dengan mutu pelayanan PKBM.

3. Terdapat hubungan yang signifikan antara persepsi pengelola terhadap program pemberdayaan dengan mutu pelayanan PKBM.

Terdapat hubungan yang signifikan antara kemampuan manajerial, motivasi kerja, dan persepsi pengelola terhadap program pemberdayaan dengan mutu pelayanan PKBM. Hubungan antar variabel sepeti terlihat dalam gambar berikut.

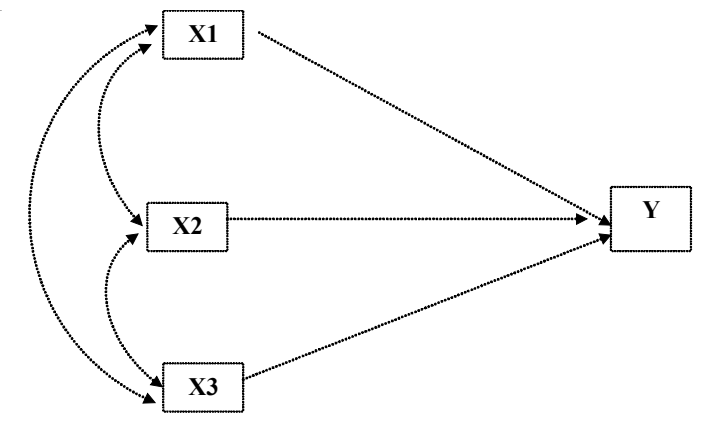

Gambar 2. Hubungan antarvariabel (bebas dan terikat)

Keterangan:

X1 = Variabel Bebas Kemampuan Manajerial

X2 = Variabel Bebas Motivasi Kerja

X3 = Variabel Bebas Persepsi Pengelola Terhadap Program Pemberdayaan

$\mathrm{Y}=$ Variabel Terikat Mutu Pelayanan PKBM

\section{HASIL PENELITIAN}

\section{Hasil Perhitungan}

Gambaran secara keseluruhan mengenai hasil perhitungan koefisien korelasi, koefisien determinasi dan persamaan regresi dapat dilihat pada tabel berikut

Tabel 2. Rangkuman hasil penelitian

\begin{tabular}{|l|c|c|c|}
\hline \multicolumn{1}{|c|}{$\begin{array}{c}\text { Hubungan antar } \\
\text { Variabel }\end{array}$} & Korelasi & $\begin{array}{c}\text { Determinasi } \\
\mathbf{r} 2 \times 100 \%\end{array}$ & \multicolumn{1}{c|}{ Regresi } \\
\hline $\mathrm{X} 1$ terhadap $\mathrm{Y}$ & 0.459 & $21.1 \%$ & $\hat{\mathrm{Y}}=27,743+0,387 \mathrm{X}_{1}$ \\
\hline $\mathrm{X} 2$ terhadap $\mathrm{Y}$ & 0.477 & $22.8 \%$ & $\hat{\mathrm{Y}}=43,569+0,309 \mathrm{X}_{2}$ \\
\hline $\mathrm{X} 3$ terhadap $\mathrm{Y}$ & 0.449 & $20.1 \%$ & $\hat{\mathrm{Y}}=40,199+0,416 \mathrm{X}_{3}$ \\
\hline $\mathrm{X} 1, \mathrm{X} 2, \mathrm{X}$ dengan $\mathrm{Y}$ & 0.612 & $37.4 \%$ & $\hat{\mathrm{Y}}=8,042+0,243 \mathrm{X}_{1}+0,170 \mathrm{X}_{2}+0,241 \mathrm{X}_{3}$ \\
\hline
\end{tabular}

Sumber : Pengolahan Data 2005

90 Jurnal IImiah VISI PTK-PNF - Vol. 2, No.1 - 2007 
Berdasarkan hasil perhitungan dan pengujian pada ketiga variabel bebas yaitu kemampuan manajerial, motivasi kerja dan program pemberdayaan terhadap mutu pelayanan program PKBM bahwa variabel yang paling berpengaruh adalah motivasi kerja $\left(\mathrm{X}_{2}\right)$ atau yang paling besar memberi kontribusi terhadap variabel mutu pelayanan program PKBM. Gambaran hubungan tersebut juga dapat dilihat pada gambar berikut

Gambar 3. Hubungan (kontribusi) variabel-variabel penelitian

1. Hubungan Kemampuan Manajerial dengan Mutu Pelayanan Program PKBM

Berdasarkan temua $\mathbf{r}=\mathbf{0 , 4 5 9}$

$\begin{array}{cl}\text { Kemampuan } & \text { ara kemampuan mana!erlal }\left(X_{I^{\prime}}\right. \\ \text { Manajerial }\left(\mathbf{X}_{1}\right) & \text { Jayanan program PKBM }(Y) \text {, ternyata } \\ & 11 \text { atau 21\%). Dengan kata lain }\end{array}$

$\mathbf{r}=\mathbf{0 , 3 7 3}$ semakin tinggi kemampuan manajerial akan Slikiasi keprada makin tingginva mutu

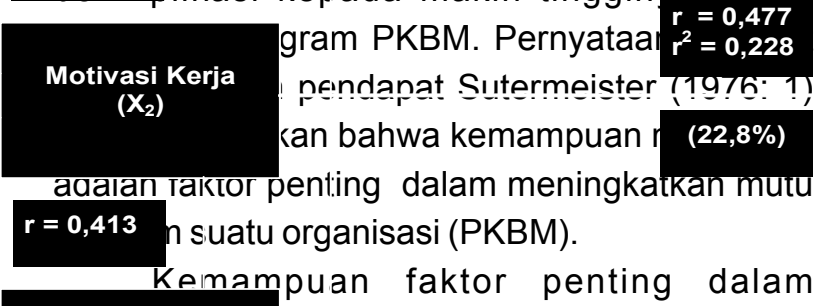

Program Pemberdayaan ( $\left.\mathbf{X}_{3}\right)$ n produktivitas kerja, karena erhubungan dengan pengetahuan jikap $r=0,449 \quad r^{2}=0,201(20,1 \%)$ sesuai dengan tugas dan fungsinya. Dengan demikian kemampuan kerja seorang pengelola \%) $\quad$ ini kemampuan managerial akan mem pengaruhi mutu pelayanan PKBM.

2. Hubungan Motivasi Kerja dengan Mutu Pelayanan Program PríBM

Hasil penelitian menunjukkan bahwa hubunaan motivasi kerja (X2) dengan mutu pe Mutu Pelayanan JKBM adalah signifikan $(0,228$ at Program PKBM menandakan bahwa semakin tir (Y) ja pengelola akan memiliki hubungan semakin tinggi pula mutu pelayanan program PKBM. Eratnya hubungan motivasi dengan mutu pelayianan sebenarnya sudah dikemukakan sebelumnya oleh David McClelland tentang need for achievernent atau N'ach. Sebagai faktor internal vasi memberikan dorongan dalam upaya mencapai kebutuhan maupun tujuan untuk berprestasi dalam bekerja.

3. Hubungan Persepsi Program Pemberdayaan Pengelola dengan Mutu Pelayanan PKBM

Berdasarkan hasil temuan penelitian bahwa hubungan persepsi pengelola terhadap program pemberdayaan dengan mutu pelayanan PKBM adalah signifikan $(0,201$ atau $20,1 \%)$. Adanya hubungan yang signifikan antara dua variabel tersebut sesuai dengan pendapat sebelumnya 
bahwa pengembangan konsep-konsep "mandiri", "partisipasi", "jaringan kerja", dan "keadilan" dalam pemberdayaan dapat meningkatkan mutu pelayanan PKBM itu sendiri.

4. Hubungan Kemampuan Manajerial, Motivasi Kerja, dan Persepsi Program Pemberdayaan Pengelola dengan Mutu Pelayanan Program PKBM

Hasil penelitian menunjukkan bahwa hubungan antara kemampuan manajerial, motivasi kerja, dan persepsi program pemberdayaan pengelola dengan mutu pelayanan program PKBM adalah signifikan $(0,374$ atau $37,4 \%)$. Hal ini menunjukkan bahwa kemampuan manajerial, motivasi kerja, dan persepsi program pemberdayaan pengelola, akan menimbulkan hubungan semakin tinggi pula mutu pelayanan programnya.

\section{KESIMPULAN DAN SARAN}

\section{Kesimpulan}

Berdasarkan hasil analisis data yang telah dilakukan dalam penelitian ini, pada akhirnya dapat ditarik beberapa kesimpulan sebagai berikut:

1. Terdapat hubungan yang signifikan antara kemampuan manajerial pengelola dengan mutu pelayanan PKBM. Hasil analisis regresi ( $Y=27,743+0,387 \mathrm{X} 1)$ menunjukkan harga yang positif dan linier. Artinya bahwa semakin tinggi nilai kemampuan manajerial pengelola maka semakin tinggi pula nilai mutu pelayanan PKBM. Hubungan kemampuan manajerial dengan mutu pelayanan PKBM berdasarkan hasil perhitungan korelasi adalah signifikan dengan determinasi 0,211 . Artinya bahwa mutu pelayanan PKBM ditentukan oleh kemampuan manajerial pengelola sebesar $21,1 \%$, sisanya dipengaruhi oleh faktor lain. Hal ini juga menunjukkan bahwa kemampuan manajerial pengelola dalam aspek berfikir, bersikap, dan bertindak dapat menjadi kontributor penting terhadap mutu pelayanan PKBM.

2. Terdapat hubungan yang signifikan antara motivasi kerja pengelola dengan mutu pelayanan PKBM. Hasil analisis regresi $(Y=43,569+0,309$ $\mathrm{X} 2)$ menunjukkan harga yang positif dan linier. Artinya bahwa semakin tinggi nilai motivasi kerja pengelola maka semakin tinggi pula nilai mutu pelayanan PKBM.

Hubungan motivasi kerja dengan mutu pelayanan PKBM berdasarkan hasil perhitungan korelasi adalah signifikan dengan determinasi 0,228. Artinya bahwa mutu pelayanan PKBM ditentukan oleh kemampuan manajerial pengelola sebesar $22,8 \%$, sisanya dipengaruhi oleh faktor lain. Dengan demikian dapat diasumsikan bahwa jika pengelola PKBM memiliki motivasi kerja yang kuat karena didasari oleh motif, harapan dan insentif yang memadai dapat meningkatkan pelayanan PKBM yang bermutu.
3. Terdapat hubungan yang signifikan antara persepsi pengelola terhadap program pemberdayaan dengan mutu pelayanan $\mathrm{PKBM}$. Hasil analisis regresi $(Y=40,199+0,416 \times 3)$ menunjukkan harga yang positif dan linier. Artinya bahwa semakin tinggi nilai persepsi pengelola terhadap program pemberdayaan maka semakin tinggi pula nilai mutu pelayanan PKBM.

Hubungan persepsi pengelola terhadap program pemberdayaan dengan mutu pelayanan program PKBM berdasarkan hasil perhitungan korelasi adalah signifikan dengan determinasi 0,201. Artinya bahwa mutu pelayanan PKBM ditentukan oleh persepsi pengelola terhadap program pemberdayaan sebesar $20,1 \%$, sisanya dipengaruhi oleh faktor lain. Dengan demikian dapat diasumsikan bahwa jika program pemberdayaan terhadap pengelola PKBM dirancang dengan baik pada tahap perencanaan, pelaksanaan dan evaluasi akan meningkatkan performance pengelola lebih baik lagi dalam memberikan pelayanan PKBM.

4. Terdapat hubungan yang signifikan antara variabel bebas gabungan (kemampuan manajerial, motivasi kerja, dan persepsi pengelola terhadap program pember-dayaan) dengan variabel terikat (mutu pelayanan PKBM). Hasil analisis regresi $(Y=8,042+0,243 X 1+$ $0,170 \times 2+0,241 \times 3)$ menunjukkan harga yang positif dan linier. Artinya bahwa semakin tinggi nilai variabel bebas gabungan maka semakin tinggi nilai mutu pelayanan PKBM.

Hubungan variabel gabungan (kemampuan manajerial, motivasi kerja, dan pemberdayaan pengelola) dengan mutu pelayanan program PKBM signifikan berdasarkan hasil perhitungan korelasi dengan koefisien determinasi sebesar 0,381 . Artinya mutu pelayanan PKBM dapat dipengaruhi oleh variabel bebas secara bersama- 
sama sebesar $38,1 \%$, sisanya dipengaruhi oleh variabel lain. Dapat diasumsikan bahwa jika kemampuan manajerial dengan motivasi kerja pengelola (faktor internal) dan program pemberdayaan (faktor eksternal) yang samasama membentuk sebagai variabel bebas kuat, maka akan meningkatkan mutu pelayanan PKBM yang kuat pula.

\section{Saran}

1. Perlunya peningkatan kemampuan manajerial pengelola PKBM melalui pemberdayaan forum, pelatihan, pemagangan, studi banding, baik yang diselenggarakan secara berjenjang oleh tingkat pusat, provinsi maupun daerah.

2. Perlunya peningkatan motivasi kerja dan motivasi berprestasi pengelola PKBM yang diberikan melalui pemberian penghargaan, kesejahteraan, dan perlindungan secara rutin terhadap pengelola PKBM yang berprestasi.

3. Perlunya peningkatan mutu pelayanan PKBM melalui peningkatan kecakapan pengelola dalam aspek personal, sosial, pedagogik, dan andragogik secara berkelanjutan.

\section{DAFTAR PUSTAKA}

Abdulhak, I. (1996). Strategi membangun motivasi dalam pembelajaran orang dewasa. Bandung: AGTA Manunggal Utama.

Al Rasyid, H. (1994). Teknik penarikan sampel dan penyusunan skala. Bandung: Jurusan Statistika Fakultas Matematika dan IImu pengetahuan Alam Universitas Padjajaran.

Amabile, T. M. (1983). The social psychology of creativity. New York: Springer Verlag.

Arif Z. M. S. (2001). Standar minimal manajemen PKBM berbasis masyarakat. Bandung: BPKBUNESCO.

Arikunto, S. (1993). Prosedur penelitian: Suatu pendekatan praktek. Jakarta: PT Rineka Cipta.

Ashkenas, R., Ulrich, D., \& Jick, T. (1995). The boundaryless organization, breaking the chains of organizational structure. San Fransisco: Jossey-Bass Publishers.

Azwar, S. (1993). Reliabilitas dan validitas. (Ed. ke-3). Yogyakarta: Pustaka Pelajar.

Balai Pengembangan Kegiatan Belajar. (2001). Standar pelayanan minimal manajemen PKBM berbasis masyarakat. Jayagiri: BPKB-UNESCO.

Craig G. \& Mayo, M. (1995). Community empowerment: A reader in participation and development. London: Zads Books.

Departemen Pendidikan dan Kebudayaan. (1991). Kamus besar bahasa Indonesia. Jakarta: Balai Pustaka.

Hardjosoedarmo, S. (1999). Bacaan terpilih tentang total quality management . Yogyakarta. Penerbit: Andi.

Hendrik. (1989). Unsur kreativitas dalam supervisi pengajaran dan pengembangan untuk belajar mengajar. Tesis, FSP IKIP Bandung.

Kaplan, R. M. \& Sacuzzo, D. P . (1993). Psycological testing pinciples, application, and issue. California: Broks/Cole Publishing Company. P.106, 123
Kenneth, J. H. \& Rosenthal, S. R. (2001). Reaching for the knowledge edge. Mexico City: Amacom.

McClelland, A., R.A Clark, \& Lowel.(1961) Achievement motive. New York: Appeton-Century-Coffs.

Nazir M. (1988). Metode penelitian. Jakarta: Galia Indonesia.

Piers, M.V. (1976). Understanding adolescence current development in adolescence psychology. Boston: Ally and Bacon.

Semiawan, C. (1984). Memupuk bakat dan kreativitas siswa sekolah menengah. Jakarta: Gramedia.

Siagian, S. P. (1995). Manajemen stratejik. Jakarta: Bumi Aksara.

Sudjana, D. (1989). Metode statistika. Bandung: Tarsito. . (2000). Manajemen program pendidikan, untuk pendidikan luar sekolah dan pengembangan sumber daya manusia. Bandung: Falah Production. . (2003). Strategi pengelolaan dan pengembangan pusat kegiatan belajar masyarakat. Visi, Diktentis Dirjen PLS Depdiknas Jakarta.

Supriadi, D. (1994). Kreativitas kebudayaan dan perkembangan Iptek. Bandung: Alfabeta.

Kindervatter, S. (1979). Nonformal education: As an empowering process. Masschusetts: Center For International Education University Of Massachusetts.

Thoha, M. (1993). Perilaku organisasi, konsep dasar dan aplikasinya. Jakarta: FISIPOL-Universitas Gajah Mada, PT Raja Grafindo Persada.

United Nations Educational, Scientific and Cultural Organization. (2003). Community learning centres. Managemen Handbook. Thailand: UNESCO Bangkok.

Zainudin M.S., A. (2001). Standar minimal manajemen PKBM berbasis Masyarakat. Bandung: BPKBUNESCO. 